\title{
足尾鉱山の探鉱法
}

正会員西野孝之

\section{On the Mining Methods at Ashio Mine}

Takayuki NISHINO

Ashio mine is one of the largest copper mine in our country, discovered by a farmer about three hundred and fifty years ago.

Since 1875, Furukawa Mining Co. has been operating this mine. In early days mining status of this mine was not so bright, but positive work on development was maintained to produce good results, that is to say, many copper rich veins, especially, the "Kajika" deposits were discovered. Since then, the production has been increased to present day level to become one of the largest copper mine.

During the World War $\mathbb{I}$, unfortunately, the prospecting work was far behind the exploitation work. Therefore, production was greatly decreased when the warwas ended. Now production has been recovered to produce 320 tons $\sim 350$ tons of copper per month by rationalization of operations and prospecting works. The principal stoping method used here is the shrinkage method.

\section{1. 緒言}

足尾鉣業所は杤木県上都賀郡足尾町飞㐫り, 日光市の 西南方約 $30 \mathrm{~km}$; 桐生市の北方約 $42 \mathrm{~km}$ の地点位位置す る。交通以両毛線桐生駅より足尾線で北に約 2 時間で通 洞駅に到着する。この外桐生一足尾一日光間のバスの便 がある。当山は古く 1610 年(慶長15年徳川二代将軍秀忠の 治世）に足尾村の農民により発見され採掘を開始したの 飞創まりその後幾多の变遷を経て明治10年古河の経営と なつた。経営当初は鉱況振わず通気排水の設備も極めて 悪く経営困難であつたが積極的な開発方針によつて，明 治16年に至り本口坑におい、て大富鉣脈横間歩銿が発見さ れ，さら飞明治18年通洞坑の開発飞着手し，明治中期以 降本山, 小滝, 通洞の三坑を中心と乙て開発努力した 結果無数の釷脈と数多の河鹿鉣床が相次いで発見され， 大正以後の盛況を見るに至つた。不幸にして第二次世界 大戦中に拉ける乱掘と探鈗不足のため戦後鉣況は極度に 悪化したが鋭意探鉣と合理化に努力した結果鉣況々゙漸次 良好となり現在は月廉銅 320 350t 程度に回復した。

\section{2. 地質鉱床}

足尾鉣床の母岩は足尾流校岩類とこれ接触して分布 する秩父古世層の砂岩粘板岩特にチャートである。足尾

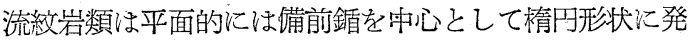
達する岩体で長軸の長さ約 $4.4 \mathrm{~km}$ 短軸の長さ約 $3.3 \mathrm{~km}$ である。立体的には基盤岩との境界が岩体の内側泊问つ

\footnotetext{
* 古河鉱業株式会社足尾放業所採鉣課長
}

て傾斜乙擂鉢状及至漏斗状の形態を呈する。この流狳岩 類より成る備前鍎山塊の下半部は主として流紋岩熔岩， 上半部は主として熔結凝灰岩から構成されている。この 山塊は噴出江先立つて基盤が陷没して擂鉢状凹地が形成 され, 次いで天狗沢付近の推定の䞇火口から熔岩火山灰, 火山燳等を噴出し，この凹地内を埋積して生成した古い 第三紀中頃の成層火山之考光られる。鉣床は裂コ充填鉣 床である鉣脈と，交代塊状或い惀状鉣床である河鹿鉣 床の 2 種類である。鉣脈注主として横間歩銿のような $60^{\circ}$ 脈之新盛銿のよう广 $100^{\circ}$ 脈の 2 系統の脈群として 流紋岩中に存在しているが，さらに流粒岩周辺の古世層 中にも相当広範围の鉣化圈を有している。鉣脈は上部に おいては多数に分岐しての数大小合せて 1,000 余条に達 しているが下部沶いてて㳊相集つて比較的小数の幹脈と なる傾向がある。河鹿鉱床は不規則な塊状筒状またはレ ンズ状をなして産する富鉱体でその数は70余であり，出 会抗河鹿群のようなチャートの擾乱帯及び流紋岩との接 触部付近が交代作用を受讨て胚胎した不規則塊状のるの を主とし，その他光盛河鹿の上うな流较岩中を筒状に上 昇した筒状鉣床とがある。鉱石は黄銅鉣を主とし黄鉄 鉣，磁硫鉄鉣，閃覀鉛鉣，硫砋鉄鉣，及び方鉛鉣等をる 産出する。

\section{3. 探鉱}

\section{$3 \cdot 1$ 坑 内概 況}

坑口は通洞及び本山の 2 籄所炕る。通洞坑口ほ海抜 $602 \mathrm{~m}$ でこれから加背 $2.7 \mathrm{~m} \times 3.0 \mathrm{~m}$ の通洞主要運搬坑道 
第 1 表

\begin{tabular}{|c|c|c|c|c|c|c|c|c|c|c|c|c|c|}
\hline & \multicolumn{2}{|c|}{ 銅 } & \multicolumn{2}{|r|}{ 系 } & \multicolumn{2}{|c|}{ 硫 } & \multicolumn{2}{|c|}{ 化 } & 系 & 合 & \multicolumn{2}{|c|}{ 坑内 1 金金山1 1 刍 } & \multirow{2}{*}{ 摘 } \\
\hline & 鉱 & 品 位 & 含 銅 量 & 精鉱含銅 & 鉱 量 & 品 & 位 & 含 銅 量 & 精鉣含銅 & 粗 & 粗鉣量 & 鉣量 & \\
\hline \multirow{4}{*}{$32 / 4$} & $t$ & $\%$ & $\mathrm{~kg}$ & $\mathrm{~kg}$ & $t$ & & $\%$ & $\mathrm{~kg}$ & $\mathrm{~kg}$ & t & $t$ & $t$ & \multirow{4}{*}{$\begin{array}{l}\text { 人員は珪肺等の長期欠 } \\
\text { 勤者を除人たによ搬出 } \\
\text { 不良 }\end{array}$} \\
\hline & 16,917 & 1.24 & 210,407 & 198,936 & 3,487 & $\stackrel{\mathrm{Cu}}{\mathrm{S}}$ & $\begin{array}{r}0.24 \\
14.30\end{array}$ & $\begin{array}{r}8,370 \\
498,693\end{array}$ & 6,451 & 20,45 & 21.8 & 13.1 & \\
\hline & 25,150 & 1.20 & 320,915 & 282,327 & 4,851 & $\stackrel{\mathrm{Cu}}{\mathrm{S}}$ & $\begin{array}{r}0.49 \\
14.26\end{array}$ & $\begin{array}{r}23,554 \\
691,914\end{array}$ & 19,756 & 30,001 & 32.2 & 19.2 & \\
\hline & 23,616 & 1.38 & 325,515 & 305,383 & 4,976 & $\begin{array}{l}\bar{C} \mathbf{u} \\
\mathrm{S}\end{array}$ & $\begin{array}{r}0.42 \\
15.25\end{array}$ & $\begin{array}{r}20,774 \\
758,832\end{array}$ & 15,737 & 28,59 & 30.8 & 18.4 & \\
\hline
\end{tabular}

汃開さくされて㧍り，その延長は $6.5 \mathrm{~km}$ に達する。ま た本山方面にも本山坑口と旧小潼坑口を結ぶ主要運搬坑 道が貫通している。この主要運搬坑道で鉱石及び採鉣用 資材の運搬を実施している。この通洞大坑道を基潐とし て $30 \mathrm{~m}$ の間隔で上部に 20 段, 下部に 10 段の加背 $2.0 \mathrm{~m} \times$ $1.5 \mathrm{~m}$ の坑道が開さくされ切羽と連結しさらにこれらの 坑道は12本の立坑及び斜坑によつて縱横に連絡してい る。これら大小坑道の総延長は現在 $1,000 \mathrm{~km}$ を突破し ている。その他坑内設備としては下部湧水を排水するポ ソプ室, 立坑の巻上機関室, 変電室, 火薬庫等である。 搬出粗鉣量性銅系 1,000t/日，硫化鉱(磁硫鉄鉣) 200t/日 であり，選鉣は別処理を実施している。32年上期（4 月 〜 月）の月別産出量及び 1 人 1 力月当出鉱量を第 1 表 示す。

\section{$3 \cdot 2$ 探 鉱}

露頭, 裂引，旧坑等の調査の結果にしたがつて有望地 区を選定し，試錐及び立入坑道によつて鉣床の有無を確 認する。電気探鉱及び化学探鉣子露頭調査及び既知鉱床 の延長, 調查等の補助手段として採用している。試錐機 は現在 8 台使用し， $7,000 \mathrm{~m} /$ 年 の探鉱を行つている。電 気探鉱は自然電位法及び比抵抗法を併用し，化学探鉱は ジチゾンによる土塊，地表及び地下水等の分析を行つて いる。稼行中の鉱床ではたえずアッセイマップを作成し て地質構造，鉣況及び釷量の正確な把握に努めている。

現在使用中の試錐機は第 2 表の通りである。

\section{$3 \cdot 3$ 採 掘 法}

当山の鉣脈は, 鉣石巾 $8 \mathrm{~cm} \sim 10 \mathrm{~cm}$ の細脈でありかつ $80^{\circ}$ 程度の急傾斜をなして却り，母岩は比較的堅硬で㐫 るため, 従来より「シュリンケージ・ストーピング」が 採用されてきた。現在も採掘法については種々に検討を 重ねているが，経済的に現在の採掘法が有利であるため 今後も継続の予定でめる。硫化鉣の採掘は，旧河鹿採掘 跡の残鉣採掘が主でありケービング，或いは空洞掘を採

第 2 表

\begin{tabular}{|c|c|c|c|c|c|}
\hline 種 & & 類 & 型 式 & $\begin{array}{c}\text { 掘さ } \text { 深度 } \\
\text { m }\end{array}$ & 保有台数 \\
\hline 回 & 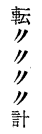 & 式 & $\begin{array}{c}\text { M. K. B. } \\
\text { '. }{ }^{1} \text { ' } \\
\text { J. R. } \\
\text { X-Ray } \\
\text { V. E. G. }\end{array}$ & $\begin{array}{r}100 \\
300 \\
120 \\
60 \\
240\end{array}$ & $\begin{array}{l}2 \\
1 \\
2 \\
2 \\
1 \\
8\end{array}$ \\
\hline
\end{tabular}

用している。主要原単位を第 3 表に示す。

第3表 原 単 位 表

\begin{tabular}{|c|c|c|c|c|c|c|c|}
\hline & 工 数 & 爆 薬 & 坑 木 & 電 力 & 鋼 材 & 摘 & 要 \\
\hline $32 / 4$ 月 & $\begin{array}{l}\text { 人I } \\
0.98\end{array}$ & $\begin{array}{r}g \\
862\end{array}$ & $\begin{array}{r}\text { 石 } \\
0.047\end{array}$ & $\begin{array}{l}\mathrm{kWh} \\
41.22\end{array}$ & $\begin{array}{r}\mathrm{kg} \\
0.043\end{array}$ & \multirow{2}{*}{\multicolumn{2}{|c|}{$\begin{array}{l}\text { 4月はストの } \\
\text { 影響岁方 }\end{array}$}} \\
\hline $\begin{array}{r}5 \text { 月 } \\
-\quad 6 \text { 月 }\end{array}$ & $\begin{array}{l}0.79 \\
0.77\end{array}$ & $\begin{array}{l}715 \\
632\end{array}$ & $\begin{array}{l}0.013 \\
0.029\end{array}$ & $\begin{array}{l}34.46 \\
34.92\end{array}$ & $\begin{array}{l}0.032 \\
0.026\end{array}$ & & \\
\hline
\end{tabular}

\section{（1）シュリンケージ採掘法}

a. 採掘集備

探鉣により捕捉した鉣脈省走向に沿つて銿劣上盤に付 けて銿押開坑（加背 $2.0 \times 1.3 \mathrm{~m}$ ) を行う。銿押開坑後 30 m間を採掘切羽の単位として採掘準備に移す。（第 1 四）

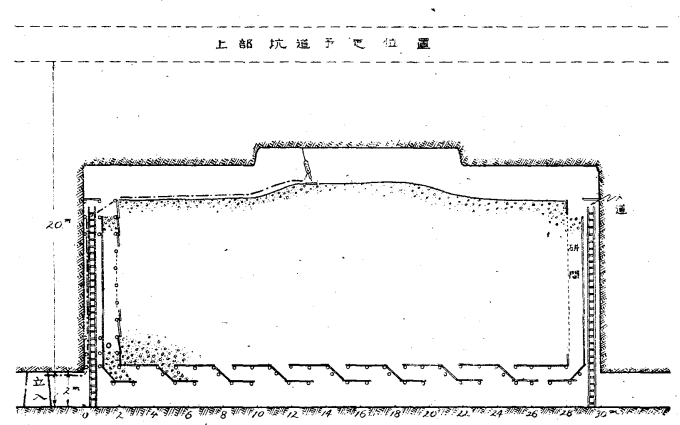

第 1 図シュリンケージ採掘法

b. 三号段払

走向延長 $30 \mathrm{~m}$ 間を一号段払，二号段払，三号段払之区 分して通常奥より階段式に払 万。加背幅は 70 90cm， 使用さく岩機は A43番型ストーパーを採用する。1方作 業量は横延び 6 $8 \mathrm{~m}$ ，上延び 80 90cm，呀孔方法は通 常千鳥型の穿孔配置であるが，とくに加背幅が狭いと か，勒性大なる岩石汇は中孔を穿孔すると起爆は良好で ある。穿孔数は30本〜40本となるので，発破の事故を防 止するため主に S Tコード点佉を採用している。な扔 電気発破も一部併用している。1 発破 $7 \mathrm{~m}$ の場合の爆薬 消費量は次表の通りである。

\begin{tabular}{l|c|c|c|c}
\hline \hline 穿孔本数 & 1 本の穿孔長 & 使用爆薬量 & 開さく量 & 爆菜量 $/ \mathrm{m}^{3}$ \\
\hline $30 \sim 40$ 本 & $80 \sim 90 \mathrm{~cm}$ & $6.5 \sim 7.5 \mathrm{~kg}$ & $5.0 \sim 6.0 \mathrm{~m}^{3}$ & $1.1 \sim 1.4 \mathrm{~kg}$ \\
\hline
\end{tabular}

c. 粗鉣搬出

積込は手積による。 $0.5 \mathrm{t}$ 三角鉣車，又は $1.0 \mathrm{t}$ 開閉鉱 車を使用し，運搬距離により異なるが 1 工取扱鉱量は 8 
〜 10t, 三号段払の粗鉣搬出完了にほ 18〜22日を要する。 d. 階段段取

留付方法には切羽の遠近, 山の状態に応じ 8 尺間取之 6 尺間取の両方式を採用している。(段取図は第 2 図に示 す）８尺間取の場合の作業要領を示すとつぎの通りであ る。

本留…軌上中心より7.3～7.5 尺を心として 5〜10 0 の傾 斜炕入礼る。

才木…本留の下方軌上より 4.2 尺のところに大れる。

止木…軌上より 4.2 尺とし才木との内のり 3.8 尺にし漏 斗スクリンを付兴場合活少し大きなるのを便用 する。

底木…第 2 図の上弓に底板の強度を考慮し 7.0 寸 1.0 尺内側飞大れる。

踏板…漏斗口の内のり 1.3 尺とする。

底板…傾斜は約 $30^{\circ} \sim 40^{\circ}$ 飞する。

通常採掘階段段取は三号段払の粗鉣搬出飞平行して本 留大を行う。留付に要する日数は 8 9 日。 $30 \mathrm{~m}$ 階段注 要する坑木は第 4 表湟す。

第 4 表 $30 \mathrm{~m}$ 階段段取所要時間及び石数

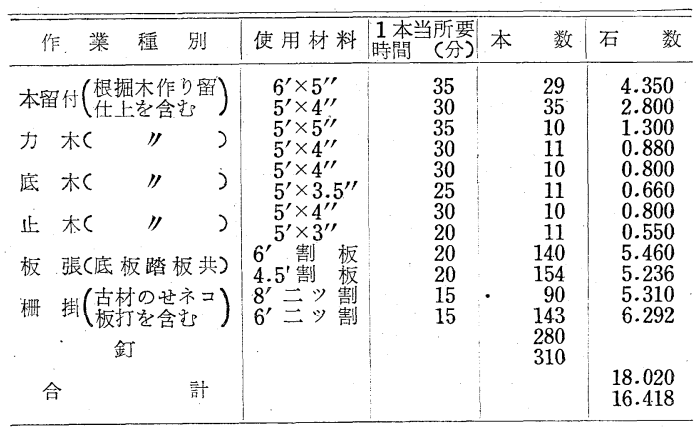

備考 表の上段は 8 尺間取，下段虫 6 尺間取を示す。

e. 採掘

漏斗付完了後本留上飞て穿孔を開始する。

i. 呀孔

穿孔方法は三号段抎と同方法を繰返すのであるが，特 に留上作業なるため粗鉣が留上に乗るまで発破に注意を

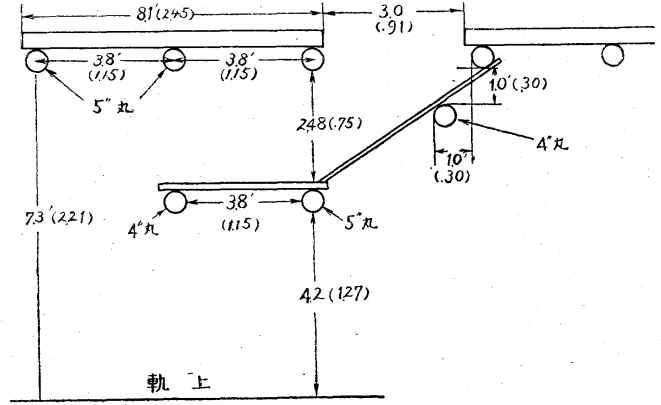

第 2 図 8 尺間取段取図

要甫る。

ii. 漏斗拔

採掘による起暴鉱量の容量が約 2 倍に増加するので常 に冠と足場との距離が $2 \mathrm{~m}$ を保つよ5適当に漏斗抜を行 亏。

iii. 人道坑井

採掘が進むにしたがい両切付において人道及び坑井を 上げて行く。坑木使用量は第 5 表に示す。作業要領は次 の通りである。(第3目)

第 5 表 階段枠上段取所要時間及び石数表

\begin{tabular}{|c|c|c|c|c|c|}
\hline 作 業 種 別 & 料 & & 数 & 数 & $\begin{array}{l}\text { 所要時間 } \\
\text { (分) }\end{array}$ \\
\hline 中 梁(眼掘りホ作り $)$ & $4^{\prime} \times 4^{\prime \prime}$ & & 1. & 0.060 & 30 \\
\hline 外梁C, ” & $\begin{array}{l}4^{\prime} \times 4^{\prime \prime} \\
4^{\prime} \times 3^{\prime \prime}\end{array}$ & & 1 & & $\begin{array}{l}30 \\
15\end{array}$ \\
\hline 垵 矢(ガラ積み贪む) & 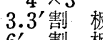 & & $\frac{1}{3}$ & 0.066 & $\begin{array}{l}10 \\
20\end{array}$ \\
\hline $\begin{array}{l}\text { 板 張(目張り含む) } \\
\text { 梯子付(モタち含む) }\end{array}$ & $\begin{array}{lll}6^{\prime} & \text { 割 } \\
6^{\prime} & \text { 割 } \\
\end{array}$ & & $\begin{array}{l}6 \\
1\end{array}$ & $\begin{array}{l}0.234 \\
0.039\end{array}$ & \\
\hline 搔 & & & 1 & 0.106 & 20 \\
\hline 合 & & & 30 & 1.605 & 145 \\
\hline
\end{tabular}

中梁…中梁と中梁の上下距離は 3.0 尺に入れる。

外梁...鉱石間の外梁は中梁より通常 3〜4 寸上げ人道間 の外梁之水平淿入れる。

柶掛…重柵にした場合は下段のコロガシを送る。

堰矢…堰矢は第 3 図の通り，3〜4枚を 5 寸位㐫けて打ち 階段内の塊石を積む。

梯子…梯子モタ七は 2 䈏所入れ釬は外側より締める。 足場板…第 3 図のよ5に鉣石間，人道間に足場板を掛け る。

通常採掘の最後の $1 \mathrm{~m}$ は上部坑道の補強のため鉣柱と して残し，2３籄所のみ切上りにて上部坑道飞貫通さ せ，粗鉣搬出完了後上部坑道の廃石充填場に利用する。 上下坑道の間隔を $20 \mathrm{~m}$ とした時 (通常は上下坑道の間 隔は切羽の状態により 異なり 15〜30m である) の採掘 日程は 65〜75 日を要する。

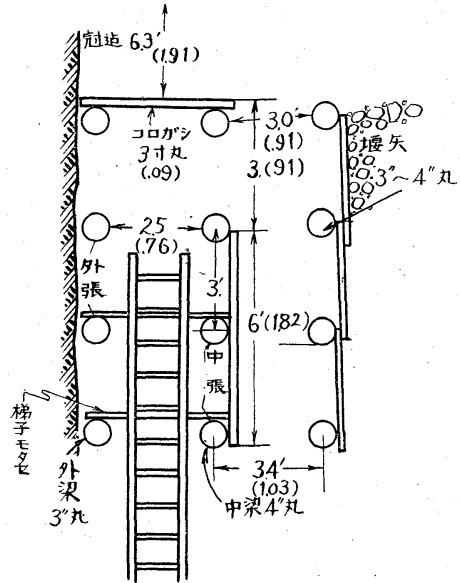

第3図

枠上段取図 
$f$. 漏斗拢 (採掘完了後)

採掘後の上下盤の状態を考慮して（盤かえりの場合山 留を大れる等) 漏斗抜を行ら。

以上が鉙脈汇括ける採掘方法であるが，一部坑木の節 減学目的と乙た改良階段法, 細脈採掘目的とし極度に 加背幅の縮少を考慮した一式採掘法等がある。昭和 32 年 5 月の工程表を第 6 表沉示す。

\section{第 6 表}

\begin{tabular}{|c|c|c|c|c|c|c|c|c|}
\hline さく岩 & 発 破 & $d$ & 岩機 1 & 台当 & 対 & 1 発 & 破 & 当 \\
\hline $\begin{array}{ll}\text { 機 } & \text { 延 } \\
\text { 台 } & \text { 数 }\end{array}$ & 回 数 & $\begin{array}{ll}\text { 開さ竟 } \\
\end{array}$ & 爆薬量 & $\begin{array}{l}\text { 対 } 1 \mathrm{~m}^{3} \\
\text { 爆薬量 }\end{array}$ & 容積 & 爆薬 & 雷管 & 導火 \\
\hline $1,197.5$ & 1,469 & $\begin{array}{r}\mathrm{m}^{3} \\
5.47\end{array}$ & $\begin{array}{r}\mathrm{kg} \\
7,265\end{array}$ & $\begin{array}{r}\mathrm{kg} \\
1,329\end{array}$ & $\begin{array}{r}\mathrm{m}^{3} \\
4.46\end{array}$ & $\begin{array}{r}\mathrm{kg} \\
5,923\end{array}$ & $\begin{array}{r}\text { 本 } \\
28.0\end{array}$ & \\
\hline
\end{tabular}

\section{（2）河鹿採掘法}

河鹿鈗床は，足尾流紋岩中の一部の富鉣体部採掘を除 いては，ほとんどチャ一ト地带に属し硬岩体の採掘が主

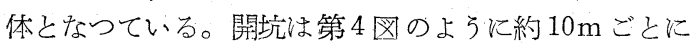
中段坑道を開さくする。

\section{a. 盤返}

第 5 図のように鉣床の範围を確認するために水平に盤 返を行 5 。穿孔方法は高さ $2 \mathrm{~m}, 3$ 本払, 穿孔数 $15 \sim 25$ 本，開さく量 $6 \sim 9 \mathrm{~m}^{3} /$ 台，手積により粗鉣を搬出する。

\section{b. 冠払}

鉱体の範围を確認した後, 冠払にて採掘鉱石を足場之 し上部採掘を行う。穿孔方法はストーパーまたはレッグ ハンマーにて扇状汇穿孔する。開さく量は10 15 $\mathrm{m}^{3} /$ 台 で岁る。粗鉣は採掘終了後手積により搬出する。以上の ような採掘を行つているのて坑木の使用量は少なく, 中 段坑道への人道坑井に要する程度である。鉱体の大きい 場合は, 適宜の間隔に鉱杜を残し採掘を行い採掘終了後 回収する。な招現在硫化鉙体の採掘においては, 河鹿周 辺の半長孔 (穿孔長 $5 \sim 10 \mathrm{~m}$ ) 発破を採用し成果を和さ
めている。

\section{4 さく岩}

\section{(1) さく岩機}

30年上期にさく岩本部々設けて科学的管理に着手し， 現在までに行つた主な事柄は次の通りである。

a. 31 年上期より 5 期更新計画を樹て 1 期に 40 台づつ 更新している。これは彷来莫大な金額を占めていたパー 卜代を節約してコンプリートで購大し，老朽さく岩機を 一掃して能率の向上を目的としている。

b. 従来は切羽に出たさく岩機は故障するまで使用し ていたので, 性能が落ちているもの, 無理な状態で使つ ているものがあつた。現在は定期検査の方式を採り， 2 〜3 カ月に 1回は修繥場で精密な検査を行つている。検 査に当つては，修繥夫の勘だけに頼らずに一繖嵌合部 は，マイクロゲージ，標集ゲージを使用し，ときには空 気消費量, 振重数の測定も行つている。

c.ささ岩簿を作り, 番号, 購大年月日, 使用したパ 一トの主な物の状況, 測定値, 稼動状況, 性能, 修理等 を記大している。これ等の事からさく岩機の状況を知 りこれを基にして種々の統制を加える基礎資料を作つ ている。

d. 使用さく岩機に直接ラインォイラー（足製 LOL50）を取り付けて，さく岩機の寿命延長，能率の向上， 油の節約を計つている。この場合に適合油をきれいな状 態で使了事が大切であり，アルモ 3 号油をポリエチレン の袋に $50 \mathrm{cc}$ (ラインォイラーの容量) 詰めたものをさく 岩夫に幾つか渡している。油の消費量は 1 分間に約 $1 \mathrm{cc}$ である。

(2) ロッドとビット

中硬岩以下の処注タングステンカーバイド (W C ) の超硬質合金をロッド直稙光にしたインサートロッドを

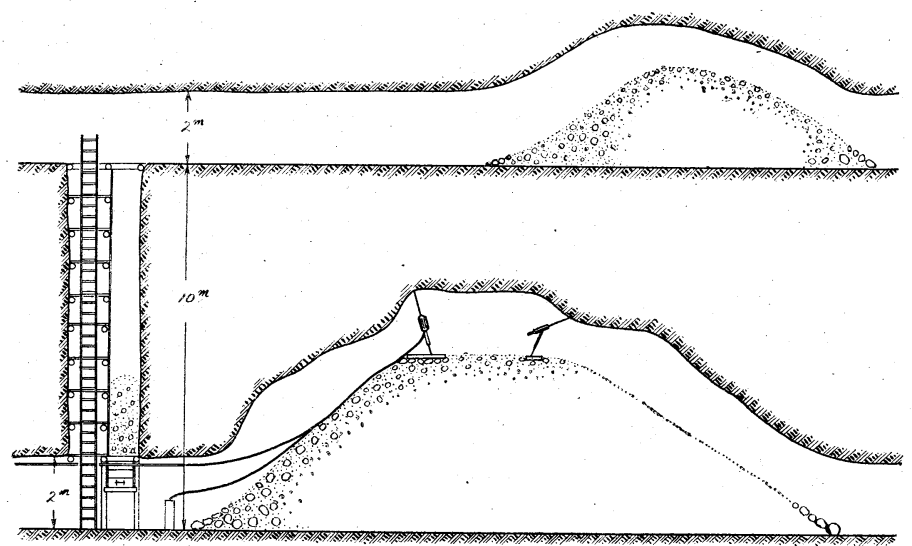

$\uparrow$

第 4 図 河 鹿 採 掘 法

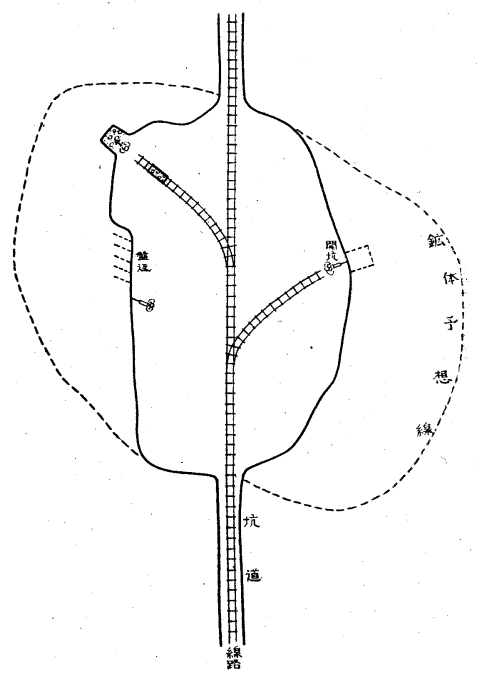


使用し，硬岩带には WC ビットをテーパー嵌合にして 使用している。(第6 図参照)

\section{a.ロッド材}

大同製鋼の $7 / 8$ ' と ${ }^{6} / 8$ " ム・モリブデンの合金鋼である $\mathrm{CR}_{3}$ を使用している。 熱処理が容易でインサートに適しているが穿孔寿命が $300 \mathrm{~m}$ 弱である。ビットのスカート材は S.N.C.M.24特 殊鋼を使用し；これは $\mathrm{CR}_{3}$ と似たものである。

b.チ・ップ

主に特工メタルを使用し，ビット用にはゲージ $38 \mathrm{~mm}$ ， 揊 $8 \mathrm{~mm}$, 高さ $13 \mathrm{~mm}$ のものを使用し, インサート用に
はゲージ $32 \mathrm{~mm}$ ，幅 $7 \mathrm{~mm}$ ，高さ $12 \mathrm{~mm}$ のものを $2 つ$ 割にして所要ゲージ $(36 \mathrm{~mm}, 34 \mathrm{~mm}, 32 \mathrm{~mm})$ に応じ て中央にデイスタンスピースを大れて使用している。製 作は鋼材とチップを支給して足尾製作所で委託加工して いる。

c. 使用状況

鋼材は寿命が約 $300 \mathrm{~m}$, 故障ロッド1本当りの穿孔長 が約 $100 \mathrm{~m}$ であるから, 再告を 2 回行つて使用した後廃 品としている。チップは穿孔 $1 \mathrm{~m}$ 当りのゲージロスが硬 岩で 0.1 0.2mm, 中硬岩で 0.03〜0.05 $\mathrm{mm}$ である。1 回 当りのリグラインドゲージロスは大体 $0.8 \mathrm{~mm}$ である。 リグラインド間の穿孔長は岩質によつ て異なり 3〜 $50 \mathrm{~m}$ ，リグラインド回数 も3〜8回でめり，インサートの故障 の無い場合は120〜200m，ビットの場 合は 60〜90m でフアイナルとなるが 故障があるので第 8 表のような結果と なる。1 回使用したチップは取外して 研摩, 整形しデイスタンスピースの大 さいのを大れて使用している。31年下 期の実績は第 7,8 表の通りである。

(3) 爆 薬 類

a. 使用状洗

1 日平均爆薬 730kg, 雷管 3,500 発, 導火線 5,000m を使つている。この外 に一部電気発破之 $\mathrm{S} \cdot \mathrm{T}$ ユード点火法 の研究を行つている。爆薬は 3 号竹ダ イナマイトと紫カーリットを主に使用 している。サイズは $30 \mathrm{~mm} \times 100 \mathrm{~g}$, $25 \mathrm{~mm} \times 80 \mathrm{~g}, 20 \mathrm{~mm} \times 37.5 \mathrm{~g}$ の 3 種 類で, テーパービットの所は $30 \mathrm{~mm}$, インサートの所は $25 \mathrm{~mm}$, その他一 部の所に $20 \mathrm{~mm}$ と 区分して使用して いる。雷管は 6 号工業雷管, 導火線は 第二種緩燃導火線を使用している。最 近 5 力月の実績は第 9 表の通りであ る。

b. $\mathrm{S} \cdot \mathrm{T}=-ト ゙$

数年前からさく岩能率が向上して, シュリンケージ採掘の場合に 1 方の穿 孔本数が 30 本〜 60本と増加してきたの で, 点火時の保安対策が閒題となつ た。この対策の一つとして米国のイグ ナイターコードやクォリーコードから ヒントを得て関東導火線株式会社で作

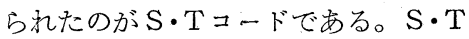
コードは 3 本の綿系を芯系にしてこれ 
第7表 ロット，ビット現況表

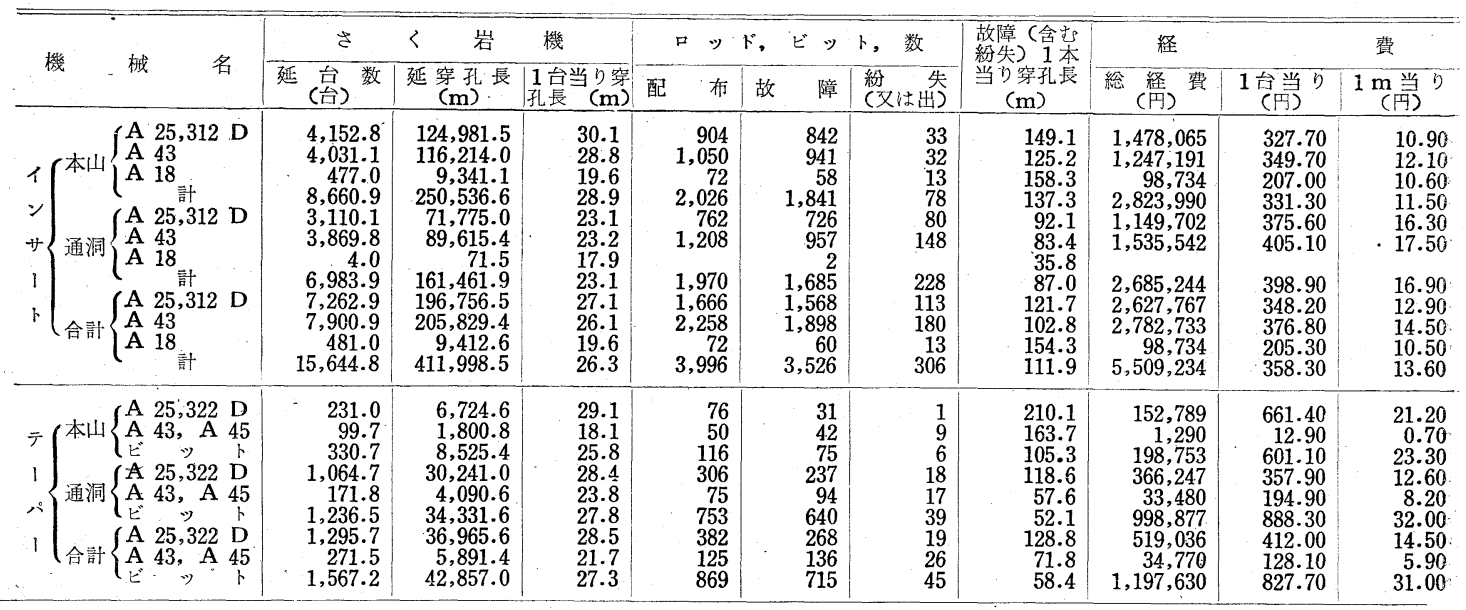

第 8 表 ロッド，ビット故障分類表

\begin{tabular}{|c|c|c|c|c|c|c|c|c|c|c|c|c|c|c|c|c|c|c|}
\hline & & \multicolumn{3}{|r|}{1} & \multicolumn{2}{|c|}{ サ } & F & ㅁ & ッ & \multicolumn{2}{|c|}{ F゙ } & \multicolumn{2}{|r|}{$\bar{\tau}$} & ー パ & $\therefore \quad-$ & ビ & ッ & 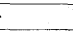 \\
\hline & & \multicolumn{2}{|c|}{ チップの 故蹱 } & \multirow{2}{*}{ 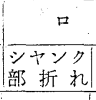 } & \multirow{2}{*}{$\begin{array}{l}\text { ツ } \\
\text { 中間 } \\
\text { 折れ }\end{array}$} & \multirow{2}{*}{ の } & 故 障 & \multicolumn{2}{|c|}{$\begin{array}{l}\text { 取扱による } \\
\text { 故 障 } \\
\end{array}$} & \multirow[b]{2}{*}{ 摩 籷 } & \multirow[b]{2}{*}{ 合 計 } & \multirow{2}{*}{$\mid \begin{array}{ll}\text { チップ } \\
\text { 脱 } & \text { 落 }\end{array}$} & \multirow{2}{*}{$\begin{array}{l}\text { チップ } \\
\text { 折 損 }\end{array}$} & \multirow{2}{*}{$\begin{array}{l}\text { スカ一 } \\
\text { 卜折这 }\end{array}$} & \multirow[b]{2}{*}{ その他 } & \multirow[b]{2}{*}{ 紛失 } & \multirow{2}{*}{ 摩粍 } & \multirow[b]{2}{*}{ 合 訫 } \\
\hline & & 脱落 & 折損 & & & & $\begin{array}{l}\text { シャンクク } \\
\text { ッ゙つぶれ }\end{array}$ & 豊の他 & 紛失 & & & & & & & & & \\
\hline $\begin{array}{l}\text { 数 } \\
\text { 比 }\end{array}$ & 量 & $\begin{array}{l}285 \\
7.4\end{array}$ & $\begin{array}{l}339 \\
8.8\end{array}$ & $\begin{array}{l}162 \\
4.2\end{array}$ & $\begin{array}{l}330 \\
8.6\end{array}$ & $\begin{array}{l}184 \\
4.8\end{array}$ & $\begin{array}{r}11 \\
0.4\end{array}$ & $\begin{array}{l}111 \\
2.9\end{array}$ & $\begin{array}{l}306 \\
8.0\end{array}$ & $\begin{array}{r}2,104 \\
54.9\end{array}$ & $\begin{array}{l}3,832 \\
100.0\end{array}$ & $\begin{array}{r}3 \\
0.4\end{array}$ & $\begin{array}{r}125 \\
16.3\end{array}$ & $\begin{array}{r}86 \\
11.2\end{array}$ & $\begin{array}{r}24 \\
3.1\end{array}$ & $\begin{array}{r}45 \\
5.9\end{array}$ & $\begin{array}{r}486 \\
63.1\end{array}$ & $\begin{array}{r}769 \\
100.0\end{array}$ \\
\hline
\end{tabular}

に黒色火薬の粉薬を流し，その上を 12 本の綿系で刨みさ らに6本の綿系を粗に巻きつけでトロセルローズや防 水性ビニール等を塗布してある。太さは約 $2.6 \mathrm{~mm}$ でキ ンク防止と伸ばし易いため $0.2 \mathrm{~mm}$ の銅線が入れてあ る。薬量は $3.5 \mathrm{~g} / \mathrm{m}$ で然焼する時は周囲に火花を散らし て花火のように燃える。耐水性は初めから問題となつた 事であるが現在では水中に30分位置いた後でも立消光す る事はない。乙かし水分が㐫ると伝火力が衰兄て燃光移 りにくくなる。 $\mathrm{S} ・ \mathrm{~T}$ コードから導火線に伝火するの に, ブランチ, コネクター等を試用したが種々の問題が あり，最近首火線の先にテンカライトを塗布したもの

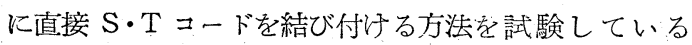
が, 不発率 $1.5 \%$ 位である。

第 9 表 開さく $1 \mathrm{~m}^{3}$ 当りの使用爆菜量 $(\mathrm{g})$

\begin{tabular}{|c|c|c|c|c|c|c|c|}
\hline 分 & $\begin{array}{c}\text { 月 } \\
\text { 類 }\end{array}$ & & 32 年 1 月 & 2 & 3 & 月 & 5 \\
\hline $\begin{array}{l}\text { 探 } \\
\text { 開 } \\
\text { 操 }\end{array}$ & 部 & $\begin{array}{l}\text { 篗 } \\
\text { 描 }\end{array}$ & $\begin{array}{l}1,848 \\
1,628 \\
1,439 \\
1,549\end{array}$ & $\begin{array}{l}1,911 \\
1,729 \\
1,477 \\
1,599\end{array}$ & $\begin{array}{l}1,958 \\
1,689 \\
1,374 \\
1,537\end{array}$ & $\begin{array}{l}1,947 \\
1,595 \\
1,337 \\
1,509\end{array}$ & $\begin{array}{l}2,023 \\
1,672 \\
1,329 \\
1,519\end{array}$ \\
\hline
\end{tabular}

(4) 穿孔法

第 7 図に示すよ5に作業基準を定め，実際にはこれを 応用した作業学行つている。

\section{5 運搬}

搬出粗鉣流一番粗鉣（製錦直送鉣石）と二番粗鉣（選 釷処理鉱石）に分類し鉣車により搬出する。な报廃石は その一部を坑内に充填し，その他は粗鉱とともに坑外に

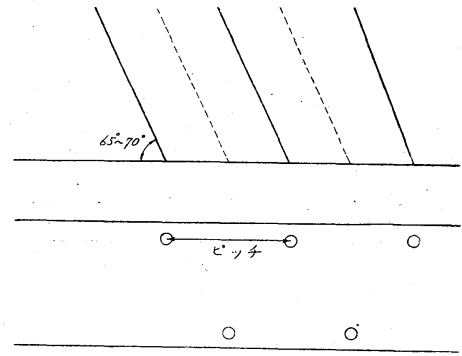

・加奉巾は原則として $80 \mathrm{~cm}$ であるが条件により異なる。したがる て係員の指示にしたがう。

・ ピツチは原則として $50 \sim 70 \mathrm{~cm}$ であるが加脊内等を考学て係員の 指示にしたがう。

- 上,下盤の差しは最大 $5^{\circ}$ とする（足場板は必ず 2 枚並べて使用の こと。

第7図階段

搬出する。積込は手積を主とし採掘切羽の状況により一 部「カーローダーリスクレーパー」等使用している。各 坑道の粗鉣は通洞地並以上は鉣石坑井または立坑ケージ により, 通洞地並以下は立坑ケージにより通洞運搬坑道 に集めて電車で通洞選鈗場に送鉣する。電車運搬工程 （31年下期）を第10表佂す。

\section{$3 \cdot 6$ 保坑及び排水, 通気}

採掘切羽の足場や坑道, 坑井, 人道の維持のため 1 力 月約 800 石の坑木類を使用している。主要運搬坑道や立 坑巻上室は鉄筋コンクリート巻を実施し切羽の状況に上 り一部クレホソート注入材を使用している箇所もある。

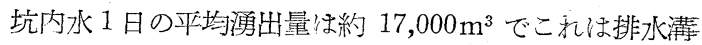


第10表 電車運搬工程（31年下期）

\begin{tabular}{|c|c|c|c|c|c|c|c|c|c|c|c|c|}
\hline 方 & 面 & 別 & 運 搬 鉱量 & 運搬距離 & $\mathbf{t}$ & 粁 数 & 金 & 物 品 費 & 力 & $\begin{array}{l}\text { 修繕費及び } \\
\text { の 他 }\end{array}$ & 経 費 合 計 & $\begin{array}{l}\mathrm{t} \text { 䉼当経費 } \\
\text { (円) }\end{array}$ \\
\hline $\begin{array}{l}\text { 本 } \\
\text { 合 }\end{array}$ & & 响 $^{\text {山. }}$ & $\begin{array}{r}54,926 \\
321,390 \\
376,316\end{array}$ & $\begin{array}{r}26,800 \\
440,146 \\
466,946\end{array}$ & & $\begin{array}{r}22,183 \\
425,551 \\
447,346\end{array}$ & $\begin{array}{l}1,756,341 \\
8,103,212 \\
9,859,553\end{array}$ & $\begin{array}{r}52,094 \\
4,808,824 \\
4,860,918\end{array}$ & $\begin{array}{r}93,543 \\
196,500 \\
290,043\end{array}$ & $\begin{array}{l}1,029,609 \\
4,059,164 \\
5,088,773\end{array}$ & $\begin{array}{r}2,931,594 \\
17,983,360 \\
20,914,954\end{array}$ & $\begin{array}{r}132.15 \\
42.25 \\
46.75\end{array}$ \\
\hline
\end{tabular}

第11表 排 水 工 程 表

\begin{tabular}{|c|c|c|c|c|c|c|c|c|c|c|}
\hline 期 別 & 排 $\begin{array}{c}\text { 水 } \\
\left(\mathrm{m}^{3}\right)\end{array}$ & $\begin{array}{c}\text { 排水量 } \times \text { 揚程 } \\
(\mathrm{m})\end{array}$ & $\begin{array}{c}\text { 使用電力量 } \\
\text { kWh }\end{array}$ & 金 & 物 & 費 & 費 & 他 & 計 & $\begin{array}{l}1 \mathrm{~m}^{3} \text { 揚水する汇要 } \\
\text { る 経 }\end{array}$ \\
\hline $\begin{array}{l}31 \text { /上 } \\
31 \text { /下 }\end{array}$ & $\begin{array}{l}4,380,048 \\
4,455,265\end{array}$ & & & & $\begin{array}{l}2,3 \\
2,0\end{array}$ & & $\begin{array}{l}4,331,756 \\
4,387,100\end{array}$ & & & $\begin{array}{l}0.653 \text { 円 } \\
0.616\end{array}$ \\
\hline
\end{tabular}

及び排水ポンプによつて坑外に排出される。本山方面上 4 番坑以上の坑内水は, 排水溝によつて本山坑口学経て 間藤浄水場に導入される。通洞方面通洞地並以上の坑内 水は排水溝により，また本山方面上 4 番坑以下は横二立 坑下 3 のポンプにより，通洞方面通洞地並以下は前銿立 坑下 8 の排水ポンプによつて通洞地並に揚水し，通洞地 並以上の坑内水とともに排水溝により中才浄水場に導大 される。通気は自然通気にて機械通気は行つていない が，下部方面で通気不良の箇所は局部扇風機を使用する ことるある。排水工程を第11表に示す。

\section{4. 結言}

足尾に和ける採掘について概要を述べたが，鉣床が広 範囲に分散して和り集約採掘が困難であり，さらに細腯 のため機械化が阻まれ主として人力に頼らざるを得ない 現状である。今後の課題としては如何にして切羽の集的 そ行うかという事である。な和機械化の問題も細胍に適 した方法を研究検討して能率の问上, 合理化による原価 切下げに努力したい。

\section{金属鉱山および非金属鉱山の資材消費量（昭和31年）}

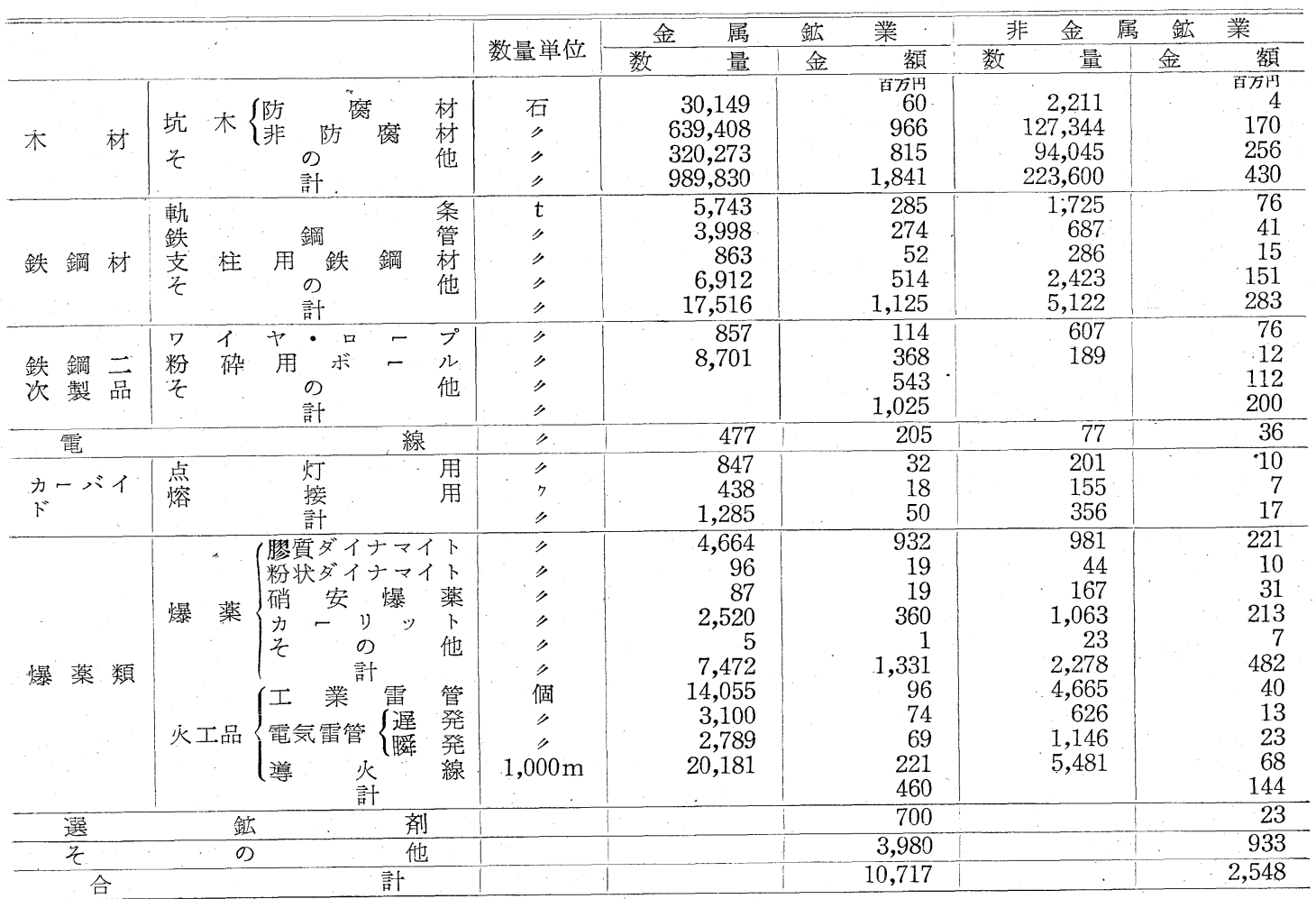

